\title{
The New Republics
}

The Czechs do not have a "Turk" of their own, which is to say, they do not have an image that immediately comes to mind when they hear the word "Turk," one fundamentally distinct from the imagery found in other countries. Even today many Czechs would perhaps think first of Hašek's famous work. The contrast he painted between Švejk's dislike of the Turks and Palivec's more businesslike outlook is used to capture the discrepancy between the negative views that some Czechs have of the Turks and the more pragmatic attitude adopted by their politicians. Most recently, this was reflected, for instance, in comments in the media on the 2019 Turkish offensive in Syria. ${ }^{1}$ The positions that Švejk and Palivec represent, however, do not cover the full spectrum of Czechs' views on the Turks, whether back in the late 19th and early 2oth centuries or even a hundred years later - and they certainly do little service to the variety of views found among those individuals who were fascinated by the Turks and their country.

Czech images of the Turks emerged in times of war with the Ottoman Empire and reflected a "real" encounter with the Turks. This experience, influential as it proved to be, posed no actual threat to the survival of the Czechs and, as time passed, their interest in the Turks waned. In the late 18th and early 19th centuries, Czech intellectual elites were instead focused on rediscovering the Czechness of the population in the Czech lands, studying their own language, history, and culture, spreading national awareness among wider social groups, and, in the second half of the 19th century, pursuing Czech political objectives. Because the Czech lands were not vitally affected by combat with the Ottoman army, the Turks did not become an important part of the 19th-century master narrative of Czech history and Czech self-identification. Nevertheless, Turkish subject matter never disappeared entirely from Czech culture, high or low. Memory of the "Turkish threat" was kept alive in folk songs and tales and in history books that told the story of Czech participation in the Turkish wars, and Turks occasionally appeared as props or minor figures in emerging modern Czech culture.

1 A recent article in a major literary magazine was titled "Do You Like the Turks? Do You Like Those Heathen Dogs?” See Jiř́ Weigl, "Máš rád Turky? Máš rád ty pohanský psy?, Literární noviny, December 16, 2019, https://www.literarky.cz/civilizace/629-mas-rad-turky-mas-rad-typohansky-psy.

(C) JITKA MALEČKOVÁ AND CHARLES UNIVERSITY, FACULTY OF ARTS, 
This imagery formed the heritage from which 19th-century Czech writers were able to draw. While representations of the Turks as fighters and as the foes of Christendom remained prominent, by the 19th century they became less sharp. These images could still be resurrected at any time with their poignancy intact, confirming Franz Stanzel's contention about the deep roots that images of Others establish in historical consciousness. Stanzel has argued that images of Others, of foreign neighbors, are so engrained in historical consciousness that they are more difficult to erase from it than are conflicts or even wars with one's neighbors and the consequences of such wars. In times of political tension and war, these images of Others re-appear or are invoked from the depths of the unconscious. ${ }^{2}$ However, there was no single image that the Czechs automatically associated with the Turks, even though the image of the Turks as fighters and as the foes of Christendom went some way in this direction. The "local" Czech way of depicting the Turks was accompanied by ideas received from abroad and images drawn from Western travelogues, novels, scholarly writings, and works on political systems. That these images did not always match the experiences, conditions, and aspirations of the Czechs mattered little given the absence of any uniform framing that views of the Turks had to fit into. Czechs had in the late 19th century no ambitions in the Ottoman Empire that needed to be justified, and turn-of-the-century Czechs were interested in the Turks for a variety of reasons, some of which changed over time, while others remained more constant. One of the most obvious motivations for the attention the Czechs paid to the Turks throughout the period that is the focus of this book, from the 1870 s to the early 1920 , had to do with the Ottoman Turks' rule over the Southern Slavs. As the Czechs' sense of closeness to other Slavs grew stronger in the 19th century, this was accompanied by increasing concern for the Southern Slavs' struggle against Ottoman rule.

In the 187os, the revolts in the Ottoman Balkans and the war that the Slavic states waged against the Ottoman Empire boosted the level of interest that Czechs showed in the Turks. Their views were at that time influenced primarily by Pan-Slavism and a sense of solidarity with the Slavs suffering under the "Turkish yoke." Earlier stereotypes did not disappear. Images of the Turks in the 1870 s often continued to be informed by religious animosity, and the Turks were depicted as the archenemies of Christendom, despite the prevailingly secular nature of Czech national ideology and the fact that there were no new religious arguments to be added to the old imagery. The Turks were also still portrayed as cruel and violent in anti-Turkish pamphlets in the 1870s, much in

2 Franz K. Stanzel, Europäer: Ein imagologischer Essay (Heidelberg: Universitätsverlag C. Winter, 1998), 11. 
the way they had been during the Turkish wars. In comparison to the past, depictions of religious difference were now occasionally accompanied and corroborated by references to racial difference, in which the Turks, as representatives of the "Mongolian race," were contrasted with Indo-Europeans. Most such views were borrowed from foreign literature and reproduced by Czech authors writing about the Turks. Other stereotypes that were commonly employed in anti-Turkish rhetoric in Western countries, such as the opinion about the despotic nature of Ottoman rule, appeared only rarely in Czech discourse. Race was not a central issue in writings on the Turks either, whether in the 1870 or or later, but it was present, and it was mostly used to provide more arguments in support of the already negative portraits of the Turks.

While most authors of anti-Turkish writings in the 1870 os did not base their descriptions of the Ottoman Turks on any personal contact with them, in the second half of the 19th and the beginning of the 2oth centuries many Czechs visited the Ottoman Empire. Their impressions were shaped in advance by the ideas they developed about the Turks from folk songs, history textbooks, encyclopedias, and anti-Turkish publications. Their own travel accounts then served as a source of information for subsequent writing about the Turks: authors who had never been to the Ottoman Empire cited them, and entries on the Turks in encyclopedias drew stories and examples from this travel literature. Travel writing thus helped to add flesh to the historical representations of the Turks as fighters and enemies by providing concrete details about their habits, way of life, and character. Because the authors of these writings were speaking from first-hand experience, the descriptions they offered came across as true representations of the Turks' character and customs, even if the authors had actually taken their information from earlier travel books.

To prepare for their trip, travelers supplemented whatever ideas they had already formed about the Turks with information they found in a variety of works, ranging from earlier Czech travel books to contemporary Western travel literature and Orientalist novels. Their actual encounter with Ottoman reality did not substantially alter the travelers' views, but some were favorably impressed by the Turks they met, and others learned to distinguish between who they deemed "the old" and who "the new" Turks. They perceived the Ottoman Empire as both backward and exotic, and in this they were often at least partly influenced by foreign writings. But they were not uniform in how they evaluated the signs of this backwardness, nor were they all persuaded that modernization had to follow the Western path. They tended to stress the backward/modern dichotomy more when they were trying to contrast Ottoman and Slavic elements in the newly emancipated Slavic countries of Southeastern Europe. 
Although they adopted many images of Turkish men and women from Western works, the way they wrote about some topics differed from Western travelogues. Travelers' views on Turkish and Muslim women are one of the more remarkable examples of these differences. Czech men who traveled to the Ottoman Empire were fascinated by the exotic beauty of women and fantasies associated with the veil and the harem, but they focused most on the position of women in society and did not portray Ottoman women as objects to be owned. Anecdotal evidence of the Czech perspective on Ottoman women is perhaps indicative of a more general characteristic of the Czechs' relationship to the Ottoman Turks, which is that it was not shaped by any colonial ambitions in the Ottoman Empire. Traveling, however, also gave Czechs an opportunity to express the sense of superiority they felt over the local population. They felt superior to the Turks - and other inhabitants of the Ottoman Empire whom they perceived to be "Oriental" - because they regarded themselves as European. But they did not (at least in their travel writings) exhibit a need to prove this, and the preeminence of Europe over the Ottoman Empire seemed self-evident to them.

The Czechs did not just view the Turks through an Orientalizing lens, but also saw the Slavs who used to live or were still living under Ottoman rule in this light, regarding them as exotic. The Czechs who visited or worked in BosniaHerzegovina, which from 1878 was occupied by Austria-Hungary, felt this to be especially true of the local Muslims there, who were of Slavic origin, but the Czechs nevertheless called them Turks. Their view of these Slavic Muslims was in fact shaped by two perspectives: one in which they were seen as Oriental and exotic and as marked by their "Turkish" (Ottoman) past, and another that claimed them as brothers and part of the larger family of Orthodox and Catholic Slavs, with whom they should be united. The Czechs took a patronizing view of the Muslim Slavs, but they viewed the Christian Slavs of Bosnia-Herzegovina, and perhaps of the former Ottoman Balkans as a whole, in the same patronizing light. ${ }^{3}$ Their relationship to the Slavs in Bosnia-Herzegovina was equally influenced by their sense of Slavic solidarity and Pan-Slavism, and this sense of closeness extended at least partly also to their Slavic Muslim brothers.

The Czechs may have referred to the Muslim Slavs as "Turks," but they clearly distinguished them from the Ottoman Turks. This distinction is evident in the way Czech visitors described the women of Bosnia-Herzegovina. The

3 They still viewed the Balkan Slavs as influenced by their Ottoman past; Todorova's claim that "the Balkans are the Ottoman legacy" corresponds with what the Czechs' views were as well. See Todorova, Imagining the Balkans, 12. 
Muslim women of Bosnia-Herzegovina seemed stranger to the Czechs than their Christian counterparts. Yet, they were not portrayed as sexual objects; they were often presented as mothers and daughters, which is to say as part of a family, and their families were explicitly depicted as Slavic. Czechs saw both Muslim and Christian Slavic families in Bosnia-Herzegovina as patriarchal, but they highlighted that Muslim families there were monogamous and that Muslim women had more rights than was common among Ottoman-Turkish women. Czech observers nevertheless often represented them as somewhat exotic and occasionally even used imagery not unlike that employed in depictions of Ottoman women. These Orientalizing portraits were found in writings by women as well as men. Czech women also participated in the Habsburg Empire's civilizing mission in Bosnia-Herzegovina, which was presented (and partly carried out) as a means by which the Czechs could help their Slavic brothers and sisters. Czech men and women generally supported the AustroHungarian occupation of Bosnia-Herzegovina and some identified with the Austro-Hungarian imperial policy in the former Ottoman provinces. Their views suggest that Czechs did not lack colonial ambitions and their "civilizing mission" rhetoric can be interpreted as a sort of colonial attitude, even if these views were not expressed in relation to the Ottoman Empire as a whole, but concerned Bosnia-Herzegovina.

In contrast, colonialism was not a significant framework of early Czech Oriental studies, although one of the field's major figures identified with the Habsburgs' imperial interests and after the emergence of Czechoslovakia expressed a kind of Czechoslovak version of colonial aspirations. The lack of an imperial tradition perhaps contributed to Czech Oriental studies' late emergence: the discipline was institutionalized in the 1880 s as part of efforts to create a full structure for Czech culture, which included developing the sort of scholarship on the Orient that existed in advanced societies in Europe in the 19th century. Czech scholars initially reproduced some ideas that were current in German-language universities, where the early Czech Orientalists studied, and also common among famous European scholars of their time. The emerging discipline was not merely a copy of foreign models though. Christian interests and the focus on theological concerns that characterized 19th-century German Orientalistik were less prominent in Czech Oriental studies. As well as the more traditional research subjects popular among Orientalists in Europe, Czech scholars were also interested in the contemporary Middle East and they were often sympathetic toward Turkish nationalism. And although modeled on Oriental studies abroad, Czech scholarship espoused ideas that set it apart from these models. The way Czech Orientalists framed their research was only in some instances inspired by the ideas that were predominantly shared by 
scholars in other countries, one such example being the belief that the West and the East were fundamentally different. Other concepts that Czech Orientalists drew on were formed out of a mixture of foreign influences and Czech nationalism; the latter in some way shaped the thinking of most early Czech Orientalists and helps explain their interest in Turkish nationalism, especially before the emergence of Czechoslovakia.

Czech Orientalists did not work in support of the Austro-Hungarian Empire, with the notable exception of Alois Musil, who allied himself with some of the Habsburgs' policies in the Middle East. For the most part, Czech scholars were motivated by an effort to enhance and strengthen Czech culture by advancing the study of the Orient, including the Turks, both on the international scene and for a Czech audience, whose intellectual horizons they sought to expand. Czech specialists in the Middle East were, however, susceptible to the same stereotypes and exoticizing images of the Muslim world that circulated among the general public. Because they were experts and very often also prominent public intellectuals, their views could then in turn confirm the Czech public's perception of the Orient as essentially different from the West, even though on the whole scholars tended to have a close and admiring relationship to at least some of the objects of their research.

Czechs who wrote about the Turks around the turn of the century in most cases backed the Austro-Hungarian Empire's policy on Bosnia-Herzegovina. In other contexts, they wrote from the perspective of their own, Czech, interests and to some extent, especially in travels, from the perspective of a European. Negative views of the Turks were often accompanied by similarly or even more negative depictions of other ethnic groups, most notably the Greeks, the Armenians, and the Jews of the Ottoman Empire, who were perceived to be just as Oriental as the Turks. The primary interpretative framework through which the Czechs viewed the Turks in the late 19th and early 20 th centuries, however, was nationalism and specifically the Czechs' sense of solidarity with the Slavs who were fighting against Ottoman rule.

Nationalism played a role also in the way images of the Turks figured in other Central European societies. The images expressed various feelings, but they primarily served as instruments in the construction of national identity and the boosting of national pride. The Turks were presented as the enemy in order to show the courage and sacrifices that were involved in the Central European peoples' fight against them. While in Czech writings this was often just a side narrative, both the Hungarians and the Poles identified themselves as Christian Europe's bulwark against the onslaught of Islam or the Turks much more vociferously and with a stronger emphasis on Christianity than the Czechs did in their national discourse, which was largely non-religious. Czechs were already being influenced to some extent in the 19th century by 
the views that prevailed among the Slovaks, who had lived through a period of Ottoman rule, but this influence only became more widespread after the emergence of Czechoslovakia. The Turks also figured as a symbol of the enemy more generally - whether that meant the Habsburgs, the Russians, or the Germans (or even the Hungarians) - and because of the past experience of war with the Turks, this symbolic imagery was salient throughout the region.

At the same time, however, the Turks were not seen only as foes and depictions of them fulfilled other functions as well. While the Czechs did not use images of the Turks to set themselves apart from the Orient because they did not identify as an Oriental or Eastern country, for Poles and Hungarians the East-West dilemma was more complex, and their attitudes ranged from selfidentifying as partly Oriental to distancing themselves from the Orient or the East and trying to prove their Western allegiance, even though they often viewed the West in a critical light. Leaving aside the Oriental influences that were embraced by early modern Polish culture and elites in particular, the Poles and Hungarians developed a warmer relationship with the Turks in the 19th century as the Ottoman Empire came to be perceived as a safe haven for Hungarian and Polish exiles, a perspective that Czechs and Slovaks did not share. For Hungarians, the Turks and the Orient played an additional role in their 19th-century search for national identity: while views on the Turks were varied and ambivalent, they were regarded by some intellectuals as the Hungarians' relatives.

Another important difference concerned the role of Slavic solidarity in attitudes toward the Turks. Generally speaking, Slavic nations in the 19th century were more concerned than non-Slavs were with the fate of the Slavs who remained under Ottoman rule. However, the Poles, because of their antagonistic feelings about Russia after the partition of Poland, were suspicious of Pan-Slavism if it involved a greater role for Russia, and in the Russo-Turkish war of 1878-1879 the Poles' sympathies did not lie with Russia. Hungarians also had little reason to support Russia, which had played an important part in suppressing the 1848 revolution, nor were they motivated to promote the emancipation of the Slavs in the Ottoman Empire, which might encourage similar efforts among the sizable Slavic population living under Hungarian rule. The Czechs thus differed from both the Poles and the Hungarians in terms of what role events in the Balkans in the 1870 s and the emergence of Pan-Slavism played in resurrecting anti-Turkish feelings among them.

An important turning point identified by Kuran-Burçoğlu in images of the Turks Europe-wide was the emergence of the Turkish Republic in $1923 .{ }^{4}$ The collapse of Europe's multi-national empires after World War I also changed

4 Kuran-Burçoğlu, “Turkey," 254-55. 
the foundations of Czech-Turkish relations. In their own new state, established on October 28, 1918, the Czechs observed with relative detachment the postwar fighting on Ottoman territories and the international negotiations that took place over the future of the Ottoman Empire. The creation of the Turkish Republic on October 29, 1923, however, made the establishment of diplomatic ties and a redefinition of economic relations between the two states a necessity. Another important aspect of mutual contacts was the position of Czechoslovak citizens in postwar Turkey. ${ }^{5}$ In October 1924 an agreement on friendship between Czechoslovakia and Turkey was signed, followed in 1927 by a trade agreement, and in April 1926 the Czech embassy moved from Istanbul to Ankara. ${ }^{6}$

In the postwar order the Czechs were positioned among those who had won the war while the Ottoman Turks belonged among those who had lost, and this had the effect of reinforcing the distance and amplifying the sense of difference between the Czechs and the Turks. Initially, Czechs tended to reject any comparisons between Czechoslovakia and Turkey. They were offended that Turkey had allegedly been treated the same way as Czechoslovakia on the international stage by the Western powers. ${ }^{7}$ Given that Turkey was of little consequence for Czechoslovakia's international position and for its commercial activities, there was no clear common line of Czechoslovak interests and policy in and toward Turkey in the interwar period. As a result, even official representatives of Czechoslovakia were not united in their stance on Turkey. ${ }^{8}$ Although the Czechs were not directly affected by the negotiations and developments in the Middle East, these events impacted their allies in the Little Entente, Romania and Yugoslavia, who were not on the best terms with Turkey. ${ }^{9}$ In September 1922, the minister of foreign affairs, Edvard Beneš, wrote that, with respect to the "Eastern Question," Czechoslovakia would back the position of Romania and Yugoslavia, adding - confidentially - that Czechoslovakia considered the Turks' "return to Europe" and their being granted possession of Constantinople

5 M. Hlavička, "Právní postavení čsl. státních př́slušníků v Turecku," Zahraniční politika 2 (1923): 273-74.

6 On postwar relations between Czechoslovakia and Turkey see Petr Novák, "Počátky československo-tureckých vztahů 1918-1926," Slovanský préhled 91, no. 4 (2005): 425-41.

7 See "Mírová konference v Lausanne," Zahraniční politika 2 (1923): 444. See also Josef Chmelař, "Problém ochrany menšin v Turecku na konferenci v Lausanne," Zahraniční politika 2 (1923): 345 .

8 This was reflected in the journal Zahraniční politika (Foreign Policy), which represented the official standpoints of the Ministry of Foreign Affairs and published articles by diplomats and scholars.

9 Josef Chmelař, “Československá zahraniční politika v r. 1922," Zahraniční politika 2 (1923): 30. 
and the Straits, and even Thrakia, to be a mistake. ${ }^{10}$ The state's official position on the Turks was at first also influenced by the sympathy some Czech political elites felt for postwar Greece, but this sympathy was quite short-lived, and Czechoslovak diplomacy thereafter kept a clear distance from the GreekTurkish conflict. ${ }^{11}$

After the Turkish Republic was established, its new leadership settled in, and especially once the modernizing reforms of Mustafa Kemal became visible the approach of some Czech politicians and political commentators started to change. The way the Turkish Republic developed after the war made it possible to view it as a country that was leaving its "Oriental" past behind it. ${ }^{12}$ After an initial period of hesitation and continuing suspicion, Czechoslovakia's political elites acknowledged that positive changes were occurring in Turkey. This shift was particularly discernible in foreign affairs, where some Czech politicians' latent distrust of the Western powers, which were perceived as important for the fate of both Czechoslovakia and Turkey, occasionally gave rise to a sense on the part of Czechs that they shared common interests with the Turks. In the early 1930s, diplomat and politician Kamil Krofta (later minister of foreign affairs) argued that, thanks to its deep "rebirth," Turkey had renounced revisionist claims and this had made possible a rapprochement between Turkey and the countries that were defending the status quo, among them "our republic."13

A certain shift can be traced also in the views of Alois Musil, who published numerous articles, aimed at both experts and a wider audience, in which he commented on current developments in Turkey. While before the war Musil's somewhat critical opinion of the Ottoman Turks was influenced by his strong sympathies for the Arabs, after the establishment of the Turkish Republic he showed more understanding for the Turks and mainly criticized the great powers' policy toward Turkey and the Middle East more generally. ${ }^{14}$ Despite some reservations, he painted an image of Turkey in which he primarily highlighted

10 Edvard Beneš, Cirkulární telegramy 1920-1935, ed. J. Dejmek (Prague: Společnost Edvarda Beneše, 2002), 58 .

11 Petr Novák, “Československá diplomacie a řecko-turecká válka 1920-1922," Moderní dějiny 15 (2007): esp. 190 and 217.

12 See Jaroslav Cebe, Anglie a Turecko: Otázka mossulská; Př́spěvek ke studiu mandátních otázek a působnosti Rady Společnosti národi̊ jako orgánu rozhodčího (Prague: Orbis, 1928), 83 .

13 Kamil Krofta, Československo v mezinárodní politice (Prague: Orbis, 1934), 23. He also published a book titled "We and the Hungarians in the Fights with the Turks." Kamil Krofta, My a Mad'aři v bojich s Turky (Prague: Státní tiskárna, 1934).

Alois Musil, "Věci turecké," Zahraniční politika 1 (1922), 1373-77. 
the progress achieved by the new Turkish government and the suffering of the Turkish population, which had been further exacerbated by the international economic crisis. ${ }^{15}$ The other early Orientalists, Rypka and Tauer (Dvořák died in 1920), did not respond to the establishment of the Turkish Republic and Mustafa Kemal's modernizing reforms with any marked change in their views and continued to publish academic work and devote substantial attention to the popularization of their research among the Czech public. In the postwar Czechoslovak Republic, Oriental studies underwent further diversification and developed more than other philological fields at Charles University's Philosophical Faculty. ${ }^{16}$ One of its representatives was Bedřich Hrozný, an Assyriologist who was the first to decipher the Hittite script and who carried out archeological digs in Anatolia in the 1920s. In a travel book he published about his journey, he praised the Turkish authorities for their support of his excavation work and demonstrated his clear fondness for Ankara, which he likened to Prague after the foundation of Czechoslovakia, while equating Istanbul with Vienna and its decline after the war. ${ }^{17}$

According to Hrozný, there were few European tourists in Anatolia, but in the interwar period a number of Czechs visited the new state. Compared to the prewar years, the travelers were more diverse. They comprised "ordinary" Czechs who traveled third class and had no advantages of status over the average Turks they observed in Turkish cities, as well as some women, such as Emílie Jahnová, a teacher who participated in a trip organized by the "Club of Friends of the Orient" in 1933 and described it in a book published the same year. ${ }^{18}$ Another travel book, titled "Across Kemal's Turkey," was published by a Czech convert to Islam. ${ }^{19}$

Despite the increasing supply and variety of travel literature and scholarly writings on Turkey that were available to Czechs in the interwar period, the public was still presented with textbooks and history books that did not offer a substantially different picture of Ottoman history than what had been asserted in the time of the Austro-Hungarian Empire. While the Turks may no longer have been called the archenemies of Christendom, they were still sometimes portrayed as cruel and vengeful, and Sultan Abdülhamid was depicted as

\footnotetext{
15 Alois Musil, "Nejistota v Turecku," Venkov, January 10, 1931, 1-2.

16 Petrán̆, "The Philosophical Faculty," 231.

17 Bedřich Hrozný, Vř́ši pưlměsíce: Cesty a výkopy v Turecku (Prague: Jos. R. Vilímek, 1927), 15.

18 Emílie Jahnová, Do Orientu (Prague, 1933), esp. 5, originally published as a supplement of the Wiener Tagebuch 1932-1933. This club was founded in Prague in 1930.

19 Mohamed Abdallah Brikcius, Napřič Kemalovým Tureckem (Prague: Československá grafická unie, 1935).
} 
a sly despot trying to exploit Muslim fanaticism. ${ }^{20}$ Like in the past, historical images of the Turks continued to serve various aims. For example, amidst the dramatic events of 1939 and the German occupation of Czechoslovakia, a major publication was released that glorified the Czechs' contribution to humankind, including their role in the Turkish wars, and it claimed that they had been denied recognition for their role by the Habsburgs and Germans, and sometimes also by the Hungarians, who wanted all the glory for themselves alone. ${ }^{21}$ The fact that the new Czechoslovak state included Slovaks, in whose historical consciousness and culture the Turks were a more prominent theme, necessarily also impacted the images of the Turks that existed in interwar society.

After the emergence of Czechoslovakia and Turkey as two independent states, a certain commonality of interests between the Czechs and the Turks was born and recognized by some Czechs. The perception that both Czechoslovakia and Turkey were "bridges" between the East and the West (albeit these two spheres were differently defined in each case) may have contributed to this feeling. However, this more pragmatic and positive attitude does not seem to have taken deep root among the general public. Across all historical changes and periods, including that of communism in Czechoslovakia, the Czechs have primarily associated the Turks with the Orient. As well as the "innocent Orientalism" of popular culture, other stereotypes of the Turks have survived, which remain latent but could be resurrected by political actors if they felt it convenient to do so or if a situation were to arise that - together with the media's coverage of it - brought back memories of "the terrible Turk." All that, however, is part of another story, which is waiting to be told.

20 Jaroslav Bidlo, Josef Šusta, and Josef Dobiáš, Všeobecný dějepis pro vyšši tř́idy středních škol, vol.3, Dějiny nového věku od osvícenství, 4th ed. (Prague: Historický klub, 1938), 59, 98, and 121. This description of the Ottoman period contrasted with the neutral and even positive depiction in the same textbook of the changes introduced in the Turkish Republic under Mustafa Kemal, who was "pushing Turkey with a firm hand in the direction of progress." Bidlo, Dobiáš, and Šusta, Všeobecný dějepis, 3:159.

21 Rudolf Urbánek, "Češi a války turecké," in Co daly naše země Evropě a lidstvu: Od slovanských věrozvěstů k národnímu obrození, ed. Vilém Mathesius (Prague: Evropský literární klub, 1939), 117-23. 